\title{
Research on the Dispute Settlement Mechanism of Intellectual Property in International Trade Under the Belt and Road Initiative
}

\author{
Li Ma \\ Law School \\ Sichuan Agriculture University \\ Ya'an, China
}

\begin{abstract}
In 2013, General Secretary Xi Jinping proposed the "Belt and Road Initiative" on April 30, 2019, China has signed 187 "Belt and Road Initiative" cooperation documents with 131 countries and 30 international organizations. The total import and export of goods between China and the countries along the route exceeded 6 trillion US dollars, with an average annual growth rate of $4 \%$, which was higher than the overall growth rate of China's foreign trade in the same period. Under the concept of win-win cooperation, countries along the route are making every effort to promote the development of international trade, and there are more and more trade disputes involving intellectual property rights in the process. Starting with the relevant intellectual property dispute settlement mechanisms of countries along the "Belt and Road Initiative" line, this paper analyzes and compares the WTO intellectual property dispute settlement mechanism with the FTA intellectual property dispute settlement mechanism. Explore the generally applicable settlement mechanism of intellectual property disputes in countries along the "Belt and Road Initiative".
\end{abstract}

Keywords - the Belt and Road Initiative; intellectual property; dispute settlement mechanism

\section{INTRODUCTION}

In 2013, General Secretary Xi Jinping put forward the "Belt and Road Initiative", which not only optimized the allocation and integration of resources and markets, but also promoted the coordinated development of national economies. With the development of high-tech industry, not only the amount of knowledge trade increases year by year, but also the content of intellectual property in goods trade and service trade is also increasing accordingly. According to the statistics of "Belt and Road Initiative" Trade Cooperation big data report (2018), China and the countries along the route account for a large proportion of the hightech products containing intellectual property rights in the import and export trade of Belt and Road Initiative. With the deepening of the "Belt and Road Initiative" cooperation initiative and the deepening of trade cooperation among countries, intellectual property disputes have emerged in endlessly. Developing countries account for the majority of the "Belt and Road Initiative" participating countries, and their level of high-tech development is relatively backward and can only be introduced from developed countries, resulting in a large number of intellectual property disputes between these countries and the developed countries along the "Belt and Road Initiative" non-route. However, the existing intellectual property dispute settlement mechanism is difficult to meet the development needs of "Belt and Road Initiative". Only by exploring a more perfect dispute settlement mechanism is the long-term plan to speed up the trade development of the countries along the route.

\section{PRESENT Situation OF INTEllectual Property DisPUTE SETTLEMENT MECHANISM IN COUNTRIES ALONG THE "BELT AND ROAD INITIATIVE"}

Globally, there are three main settlement mechanisms for intellectual property disputes between different countries. One is multilateral trade agreements between countries, such as the WTO. The other is regional free trade agreements between countries, such as the NAFTA. The third is bilateral trade agreements between countries. The development level of the countries along the belt and the road varies greatly, and most of them are developing countries. Therefore, the first two kinds of intellectual property disputes are more applicable for these countries to solve intellectual property disputes.

\section{A. Overview and Disadvantages of the World Trade Organization (WTO) Intellectual Property Dispute Settlement Mechanism}

At present, the existing intellectual property disputes between countries with available information are that the disputes mainly arising from the rights and obligations under the Agreement on Trade-Related Aspects of Intellectual Property Rights (TRIPS) among the member countries of the WTO. When joining the WTO, TRIPS is one of the agreements that must be signed. Any country that wants to join the WTO must meet a minimum protection standard which covers the object of protection and the period of protection. When any member state's participation in or formulates intellectual property treaties and agreements does not meet the provisions of TRIPS, the country will face intellectual property disputes with other member states. According to statistics from the official website of WTO, on 
March 1, 2019, there were 40 cases related to intellectual property disputes among WTO members, of which fifteen were related to the countries along the belt and the road. Those countries had nine pieces as the complainant. And between 2017 and 2018, there are six cases had occurred between those countries. As a member of WTO, the countries along the routes have chosen the dispute settlement mechanism under WTO to settle disputes after the disputes arising from intellectual property rights.

According to The Dispute Settlement Understanding, the WTO dispute settlement mechanism procedures mainly include diplomatic means such as consultation, good offices and judicial means such as panel ruling, appeal review, etc. The biggest feature of which is the establishment of Dispute Settlement Body, the authoritative dispute settlement institution. After the member states submit the dispute to WTO, DSB agency makes the final ruling with enforcement force through judicial procedures, which guarantees the smooth settlement of the dispute to a certain extent. The DSU procedure also applies to the settlement of intellectual property disputes between WTO members. DSU is similar to the procedural law, which makes detailed provisions on the procedural elements of dispute settlement. TRIPS is similar to the substantive law, and its provisions are the basis for the practical settlement of intellectual property disputes. DSU procedure and TRIPS are combined with each other, and they complement each other and form a complete WTO intellectual property dispute settlement mechanism.

It is the choice of most member countries to settle the intellectual property disputes in international trade through WTO rules. However, for the WTO member states along the "Belt and Road Initiative" route, there are still some drawbacks in the practical application of the intellectual property dispute settlement mechanism under the WTO. In terms of substance, the rights and obligations related to intellectual property between developed countries and developing countries are unequal in TRIPS. Most countries along this route are developing countries, and their intellectual property status varies from country to country. While the establishment of TRIPS is mostly developed countries, the minimum standards for intellectual property protection that it stipulates and requires all member countries to meet are obviously not in line with the national conditions of developing countries. This is not conducive to the development of developing countries, and may even widen the gap between developed and developing countries in the level of high-tech development. In terms of participation, on March 19, 2019, only seven countries along the belt and the road, including Congo and The United Arab Emirates, are not members of the WTO. Although most of the countries that joined the WTO along this route account for a large proportion of the countries, but because of the content of the treaty, only a small proportion of the countries along the WTO intellectual property dispute cases are involved, and the participation rate is very low, and most of them are in a very unfavorable position of the complainant. In terms of solving procedure, DSU mechanism also has some defects. For example, the expert groups involved in dispute settlement are not full-time personnel. Most of them are selected from the staff of national governments after the occurrence of disputes. There is no fixed standard for their qualification examination, which is relatively unfair. Another example is the small number of judges in the permanent appellate body, which may lack impartiality and independence. All these are very detrimental to the settlement of intellectual property disputes in countries along the "Belt and Road Initiative" route.

\section{B. Overview and Defects of the Free Trade Agreement (FTA) Intellectual Property Dispute Settlement Mechanism}

There are many countries along the "Belt and Road Initiative" route and the development level of each country is quite different. Although some countries do not have largescale intellectual property disputes, there are still intellectual property related frictions. At the same time, due to some defects in the WTO dispute settlement mechanism for intellectual property, which is not conducive to the protection of the rights of developing countries, some intellectual property disputes between WTO members along the route and seven non-member states of WTO are often settled by bilateral or multilateral treaties.

A bilateral treaty is a negotiated treaty between two countries that applies to the settlement of disputes between only the two countries. To solve the intellectual property disputes of the countries along the route through bilateral treaties may have problems such as small scope of application and longtime consumption. So far, there have been few bilateral treaties between countries along the "Belt and Road Initiative" route that deal with intellectual property disputes.

In view of the fact that the WTO dispute settlement mechanism cannot well fit the development of "Belt and Road Initiative" and bilateral treaties are not universal, the multilateral regional free trade agreement has become one of the most widely applicable dispute settlement mechanisms adopted by countries along the "Belt and Road Initiative" . However, this dispute settlement mechanism is not fully applicable to the settlement of intellectual property disputes in those countries.

On the one hand, most of the free trade agreements that countries along the "Belt and Road Initiative" participate in have imperfect provisions on intellectual property and the corresponding dispute settlement mechanism. In our country, for example, according to the China FTA Network official statistics as of September 2018, China has signed nearly twenty free trade agreements, including twelve countries along the belt and the road, accounting for 3/4 of China's total signed agreements. However, in these free trade agreements signed between China and those countries, most of them only have principled provisions on intellectual property issues, and few have substantive contents. For example, the China-Costa Rica Free Trade Agreement only provides general provisions on intellectual property through articles 109 to 117 , and there is no solution for intellectual property disputes. For another example, although the ChinaNew Zealand Free Trade Agreement contains a solution to 
the intellectual property dispute, it only provides for the common diplomatic means of consultation. The ChinaSingapore Free Trade Agreement does not even make any provision for intellectual property. In most cases, member countries cannot protect their intellectual property through these free trade agreements.

On the other hand, the provisions of these free trade agreements on the universal dispute settlement mechanism are not perfect. Take the agreement between China and ASEAN on the dispute settlement mechanism as an example. The ten ASEAN countries are closely connected with China in the "Belt and Road Initiative" strategy, and the ChinaASEAN Free Trade Area is one of the most influential free trade areas involved in the "Belt and Road Initiative" initiative. Although this agreement is one of the most perfect regional trade agreements among the countries along the belt and the road, the dispute settlement mechanism provided by it is not perfect. There are only three general methods of dispute settlement specified in the agreement: consultation, mediation and arbitration. Of the three methods, arbitration is the only one with stronger mandatory law. The former two dispute settlement methods have a greater randomness and freedom, making the settlement of relevant issues more difficult and take too long. At the same time, article 4, paragraph 4 of the agreement stipulates that the parties to the dispute shall make the best efforts to complete the negotiation. This provision makes the parties to the dispute often choose negotiation as the first choice for the settlement of the dispute. However, the arbitration matters stipulated in the agreement are rarely used in practice. In the process of dispute settlement, consultations often rely on diplomatic means between countries, which can only play a role in promoting the settlement of disputes between the two sides and cannot guarantee the substantive settlement results. In the course of consultations, if one of the parties suddenly backtracks, the dispute cannot be resolved. The dispute settlement mechanism of consultation is highly unstable. The universal dispute settlement mechanism is not perfect, and there are no detailed provisions for dispute settlement mechanism related to intellectual property, which is obviously not conducive to dispute settlement. Therefore, there are still defects in applying FTA dispute settlement mechanism to solve intellectual property disputes.

Although the existing mechanism can solve some intellectual property disputes in countries along the "Belt and Road Initiative", it still has many defects. As far as the WTO intellectual property dispute settlement mechanism is concerned, it can be said that it is a relatively complete and comprehensive mechanism in the contemporary era. However, so far, some countries along this route have not "joined the WTO", so this mechanism cannot be applied. At the same time, as most of the WTO mechanism makers are developed countries and the procedures are partly defective, which is not conducive to the appeals of developing countries. And the participation of countries along the belt and the road is still not high. In terms of regional free trade agreements, the intellectual property dispute settlement mechanism in the free trade agreements of developed countries is relatively complete, but in terms of developing countries, the intellectual property dispute settlement mechanism in the FTA still has defects. Taking ASEAN as an example, in fact, there are not only a few regional trade agreements involving "Belt and Road Initiative", but most of them are similar to the China-ASEAN dispute settlement mechanism of intellectual property rights. There is only a general dispute settlement mechanism. There is no systematic stipulation. Most of the regional trade agreement participation countries choose negotiation and other diplomatic means to settle disputes, rather than mining them. It is not conducive to the settlement of disputes to adopt legally binding methods, but diplomatic means tend to be arbitrary and unstable. There is only a general type of dispute settlement mechanism, without the regulation of the system, no more detailed terms of intellectual property rights dispute resolution. Most countries participating in regional trade agreements choose to settle disputes through diplomatic means such as consultation rather than legally binding means. However, diplomatic means are often arbitrary and unstable, which is not conducive to the settlement of disputes. Some regional trade agreements even have a general framework and no specific dispute settlement mechanism. In the case of bilateral trade agreements, this is the least dispute resolution option available to countries along the route. Due to the different legal levels and economic development of the countries along the route, few countries have concluded the relevant treaties on intellectual property dispute settlement mechanism. Without joining the same multilateral trade organization or participating in the same regional trade agreement, most countries adopt diplomatic means to settle disputes instead of signing a bilateral treaty.

\section{IMPROVEMENT OF THE EXISTING INTELLECTUAL} Property Dispute SETTLEMENT MECHANISM AgAINST THE

BACKGROUND OF THE"BELT AND ROAD INITIATIVE"

The existing "Belt and Road Initiative" intellectual property dispute settlement mechanism is dominated by multilateral trade agreements and regional free trade agreements, which has both advantages and disadvantages. The "Belt and Road Initiative" initiative aims to build an economic and trade community based on existing regional cooperation platforms. It is necessary to make use of the existing typical multilateral trade agreements and relevant provisions in regional trade agreements to take the essence and improve the existing intellectual property dispute settlement mechanism in the countries along the routes.

\section{A. Promoting the Reform of the WTO Mechanism and Improving the WTO Intellectual Property Dispute Settlement Mechanism}

Although the WTO mechanism has some defects, so far the vast majority of intellectual property disputes between countries have been solved through the WTO mechanism.It is necessary to promote this typical intellectual property dispute settlement mechanism reform and make it perfect, in line with the trend and characteristics of "Belt and Road Initiative".

First is to further promote the application of WTO dispute settlement mechanism. Joining WTO means that the 
economy of many developing countries can develop more rapidly. However, due to cumbersome negotiation procedures and lack of experience, many underdeveloped countries face difficulties in the accession negotiations. So far, there are still countries along the line is not a member of the WTO. Therefore, China, as the leading player of the "Belt and Road Initiative", can help some countries to negotiate and contribute to their accession to the WTO. This will not only enable more countries to make full use of the WTO dispute settlement mechanism, but also better promote the improvement of the WTO mechanism.

Second is to promote the standardization of legislation and establish a reasonable intellectual property protection intensity testing system. Standardized legislation makes the writing of relevant treaties more rigorous and precise. Only with a rigorous treaty can judges have the criteria for evaluation, guarantee the fairness and justice of the results, and promote the wide recognition and application of the dispute settlement mechanism. Strict treaties reduce the discretion of judges and protect the interests of developing countries to a certain extent. At the same time, the "minimum intensity" required by TRIPS is not accessible to all countries, which limits the development of some developing countries. The establishment of a test system through detailed legislation can adapt to the specific national conditions of different countries, abandon the "generalizability" and establish a "suiting to local conditions" treaty.

Third, strengthen international cooperation among countries to promote common development. In the process of international trade, international cooperation is the most important, and so it is in the process of international dispute settlement. Strengthening international cooperation involves many aspects, such as legislating treaties through friendly agreements and improving dispute settlement mechanisms. It can also strengthen the enforcement of intellectual property through the cooperation of various countries in law enforcement.

\section{B. Learning from the Existing NAFTA Mechanism and Improving the Regional Intellectual Property Dispute Settlement Mechanism}

Most of the countries along the "Belt and Road Initiative" route are developing countries. This not only restricts the development of their own domestic laws but also restricts the dispute settlement mechanism in the regional trade agreements they participate in or lead. As an example, the China-ASEAN dispute settlement agreement mentioned above stipulates three settlement mechanisms. However, after disputes arise, countries of both sides still adopt diplomatic means rather than resorting to dispute settlement mechanisms. Along at the same time, compared with developed countries of the country to participate in the regional trade agreement, signed mostly in developing countries, is not perfect, so the regional free trade agreement between the developed country for reference of the dispute settlement mechanism can better promote the country along the "Belt and Road Initiative" to establishment of the regional intellectual property dispute settlement mechanism.
The North American Free Trade Agreement (NAFTA) is a comprehensive trade agreement signed by the United States, Mexico and Canada. The three countries have a large gap in politics, economy and culture, which is similar to the "Belt and Road Initiative" member countries. Therefore, NAFTA is of great reference significance for the establishment of the "Belt and Road Initiative" new intellectual property dispute settlement mechanism. NAFTA classifies dispute settlement mechanisms according to different objects. Although intellectual property disputes are not separately classified into one category, in the definition of "investment" in Chapter 11, intangible intellectual property rights are included as a kind of property. Its provisions are applicable to dispute settlement between one party and another investor, and do not belong to the dispute settlement parties discussed in this paper. While Chapter 20 provides for a general dispute settlement mechanism applicable to intellectual property disputes between contracting states, unlike the WTO dispute settlement mechanism, the free trade commission and the AD hoc panel of experts set up on a case-by-case basis are the main bodies in NAFTA to assume the functions of the dispute settlement mechanism. The free trade commission, which is composed of officials at the parliamentary level of member states, is responsible for making treaties, supervising implementation, and resolving disputes. When a dispute cannot be settled amicably, the panel may proceed to arbitration, producing a final arbitration report.

As a typical regional trade agreement, NAFTA has its own obvious advantages. First of all, the dispute settlement mechanism stipulated by NAFTA is a good combination of diplomatic and legal means. When disputes can't be settled through mediation and consultation, compulsory arbitration means can be used as a final solution. Instead of separating diplomatic means from legal means like "China-ASEAN", some countries are in a dilemma of being unable to resolve disputes after being "repented". Secondly, NAFTA has set up a "Free Trade Committee" as a third party to supervise the implementation of the agreement. The committee can not only mediate in the negotiations between countries, but also supervise the expert group in the arbitration stage.

The author believes that in the process of improving the existing regional intellectual property dispute settlement mechanism in countries along the "Belt and Road Initiative", the relevant provisions of NAFTA can be referred to according to the specific situation. For example, when signing a regional trade agreement, a third-party organization that does not belong to any country can be established to be responsible for the dispute settlement of intellectual property in combination with the characteristics of the number of countries along the "Belt and Road Initiative" and the disparity in development level. In the use of regional trade agreements to resolve intellectual property disputes, the third party is in charge to protect the interests of the less developed countries. 


\section{CONSTRUCTION OF A NEW INTELLECTUAL PROPERTY DisPUTE SETTLEMENT MECHANISM AgAINST THE BACKGROUND OF THE "BELT AND ROAD INITIATIVE"}

WTO dispute settlement mechanism and the dispute settlement mechanism in the regional trade agreement are the most solutions adopted by countries along the "Belt and Road Initiative" to solve intellectual property disputes. In order to promote the settlement of the "Belt and Road Initiative" intellectual property disputes, it is bound to improve the two. But in fact, due to the regional characteristics, WTO dispute settlement mechanism cannot perfectly solve the intellectual property disputes among the countries along the routes, and regional trade agreements also have big problems. Therefore, in order to better solve the intellectual property disputes of all participating countries along the routes, it is essential to build a new intellectual property dispute settlement mechanism.

\section{A. Promoting RCEP Negotiations and Building the Basis for a New Model}

Regional Comprehensive Economic Partnership (RECP) is put forward by the ten ASEAN countries saw for the first time, invite the six countries such as China, Japan, South Korea, dominated by the association of ASEAN regional economic integration, it still belongs to the product of the regional economic integration, but unlike the ASEAN Free Trade Area, the RCEP member states are highly coincident with the countries along the belt. Their basic principles and ideas are very similar, including developed countries and developing countries, covering a very wide range. Therefore, the author believes that the intellectual property dispute settlement mechanism formed by RCEP in the future must be an Asian exclusive model in line with the corresponding national conditions of most developing countries. It is of great significance to promote the negotiation of such an "Asian model" for the establishment of a new model of the "Belt and Road Initiative" intellectual property dispute settlement mechanism. As there are so many countries along the "Belt and Road Initiative" route, it takes a lot of time to establish a new intellectual property dispute settlement mechanism with the participation of all countries along the route, and disputes will still arise during this period. By advancing RCEP negotiations first, it is not only possible to have a more detailed understanding of the attitudes and opinions of countries with different levels of development towards the settlement of intellectual property disputes, but also possible to take it as a basis for the improvement of the new dispute settlement mechanism, so as to make it richer in the "Belt and Road Initiative" exclusive feature and save time and cost.

By the end of 2018, negotiations on the RCEP were close to 80 percent, and many chapters had been completed, but negotiations on the intellectual property chapter and related dispute settlement mechanism chapters had not yet been completed. According to the guiding principles and purposes of the RCEP published on the official website of ASEAN, intellectual property rights and their dispute settlement are an indispensable part of the RCEP. Therefore, to accelerate the negotiation of relevant chapters of the RCEP on intellectual property rights can lay a foundation for the establishment of a new type of exclusive intellectual property dispute settlement mechanism known as "Belt and Road Initiative" as soon as possible.

\section{B. Integrating Existing Mechanisms and Establishing a New Model Structure}

In the process of building a new intellectual property dispute settlement mechanism, it is obviously inappropriate to completely abandon the existing rules. It is necessary to build a new mode structure suitable for the status quo of the "Belt and Road Initiative" on the basis of integrating the existing mechanism.

First, because of the diversity of intellectual property disputes between countries, it is necessary to establish new institutions to promote the establishment of a diversified intellectual property dispute settlement mechanism. The author believes that in the process of establishing the new model of the "Belt and Road Initiative" intellectual property dispute settlement, legal means should be the last line of defense, supplemented by diplomatic means, to ensure that every dispute can be effectively resolved. At the same time, China can take the lead in setting up a new body to be dedicated to dispute settlement, involving mediation in the stages of consultation and mediation, and supervision in the judicial stage to ensure the impartiality of dispute settlement.

Secondly, due to the strong professionalism of intellectual property rights, it is necessary to learn from the expert group in NAFTA and participate in the dispute settlement in the whole process. After a dispute occurs, a panel of experts can be organized by a specialized agency to assess the facts and provide professional advice in the diplomatic stages of consultation and mediation, so as to increase the probability of success, and provide professional advice to the judge to ensure fair adjudication in the judicial stage. However, it is different from NAFTA temporary expert group. The author believes that a group of fixed members can be selected through strict screening conditions, so as to ensure the consistency of the application of the treaty and guarantee fairness and justice.

\section{Creating a New Online Dispute Settlement Model with Contemporary Features}

With the advent of the era of big data, the model of "Internet + " has been deeply rooted in the hearts of people. All kinds of platforms are connected with the network, and the judicial system has not fallen behind. The explanatory document Technical Guidelines on Online Dispute Resolution issued by the United Nations Commission on International Trade Law in July 2016 is a reference for domestic online dispute settlement. In recent years, China has carried out online arbitration and online trial system in many places. The online dispute settlement model can not only change the previous cumbersome trial process, but also make the trial method more flexible.

During the in-depth promotion of the "Belt and Road Initiative", the dilemma of intellectual property dispute settlement of all countries is not only that there is no suitable 
dispute settlement mechanism, but also that the time limit is long and the cost is high. To truly resolve intellectual property disputes in countries along the "Belt and Road Initiative" route, just establishing a mechanism is not enough. The new mode of "Internet + " has improved the complexity of domestic litigation procedures. If it can be applied to the dispute resolution of all countries along the belt and road, it can also solve the problems of long time, high cost, hard evidence and complicated process, which has great advantages for the timeliness and professionalism of intellectual property disputes. This model is not only applied to "Belt and Road Initiative" diplomatic means, but also to judicial means.

China is the leader of the global network technology industry and the leader of the "Belt and Road Initiative". It has great advantages in establishing the new model of "Internet +". China can organize the development of a specific transnational network platform for the settlement of intellectual property disputes at home, and invite countries along the "Belt and Road Initiative" to join the dispute settlement platform by signing agreements. In the stage of mediation and consultation, the parties to a dispute can transfer information through a specific network platform. The platform can also intervene in mediation after professional investigation to try to balance the demands of both parties through professional opinions. If both parties reach an agreement through negotiation, they can also make use of the platform to make compensation and other subsequent steps. In the judicial process, as the issue of intellectual property rights often involves many countries, no matter which country the offline court session is held, the other side will feel unfair. But once you have this platform both individuals and countries can use this Internet platform to arbitrate or litigate without meeting. This also solved the problem of the venue. Such a transnational network platform can not only be a choice to solve intellectual property disputes among countries along the "Belt and Road Initiative", but also a way to solve intellectual property disputes among enterprises of different countries. If this new model can be confirmed by most countries, the author believes that it can even be considered to be generalized, rather than just applied to intellectual property disputes.

Of course, online dispute resolution as a new thing has its drawbacks. For example, how to determine the qualification of the platform and how to protect the privacy of both parties is issues that is necessary to think about and improve.

\section{CONCLUSION}

Through the above analysis of the intellectual property dispute settlement mechanism of the countries along the "Belt and Road Initiative", the author believes that to solve the intellectual property dispute problems of those countries, not only the existing mechanism needs to be supplemented and improved, but also a new mechanism that belongs to the "Belt and Road Initiative" should be built. However, due to the different economic, political and other national conditions of the countries along he "Belt and Road Initiative" route, it is difficult to unify the applicable intellectual property dispute settlement mechanisms. In order to promote the development of the "Belt and Road Initiative" trade, China, as the leading player of this initiative, should establish an intellectual property dispute settlement mechanism suitable for countries along the "Belt and Road Initiative" line on the basis of learning from existing mechanisms and combining with contemporary characteristics. In this way, it can not only solve the intellectual property dispute of the "Belt and Road Initiative", but also contribute to the international intellectual property system.

\section{REFERENCES}

[1] Zhang Naigen.Jurisprudence or Precedent? Treaty Interpretation of Appellate Body and Reform of WTO Dispute Settlement Mechanism [J] . International Economic Review,2019(2):44-56.

[2] Luo Sheng, Nie Changzhen. The Development and Prospect of online dispute settlement Mechanism under the background of Belt and Road Initiative $[\mathrm{J}]$. Wu Han University International Law Review, 2018, 2 (02): 25 -36.

[3] Wang Nan. Dilemma and outlet: a study on the International intellectual property dispute settlement Mechanism under the background of Belt and Road Initiative [J]. Electronic intellectual property, 2017 (12): 65-74.

[4] Hua Jie. Review of intellectual property Chapter of Regional Comprehensive Economic Partnership Agreement [J]. Journal of Chongqing University of Technology (Social Science Edition), 2017, 31 (05): 66-73.

[5] Zheng Xuwen. The Construction of pluralistic dispute settlemen Mechanism under the initiative of Belt and Road Initiative [J]. Journal of Dalian Maritime University (Social Science Edition), 2018, 17 (05): 22- 30

[6] Lu Guang. Defects and perfection of WTO dispute settlement Mechanism [J]. Journal of Chi Feng College (Chinese philosophy and Social Sciences Edition), 2014, 35 (08): 104-105.

[7] Sun Wen. The Integration of Justice and Arbitration: the characteristics of NAFTA dispute settlement Mechanism [J]. Legal Review of Nanjing University, 2005 (01): 249.-259. 